Provided for non-commercial research and education use. Not for reproduction, distribution or commercial use.

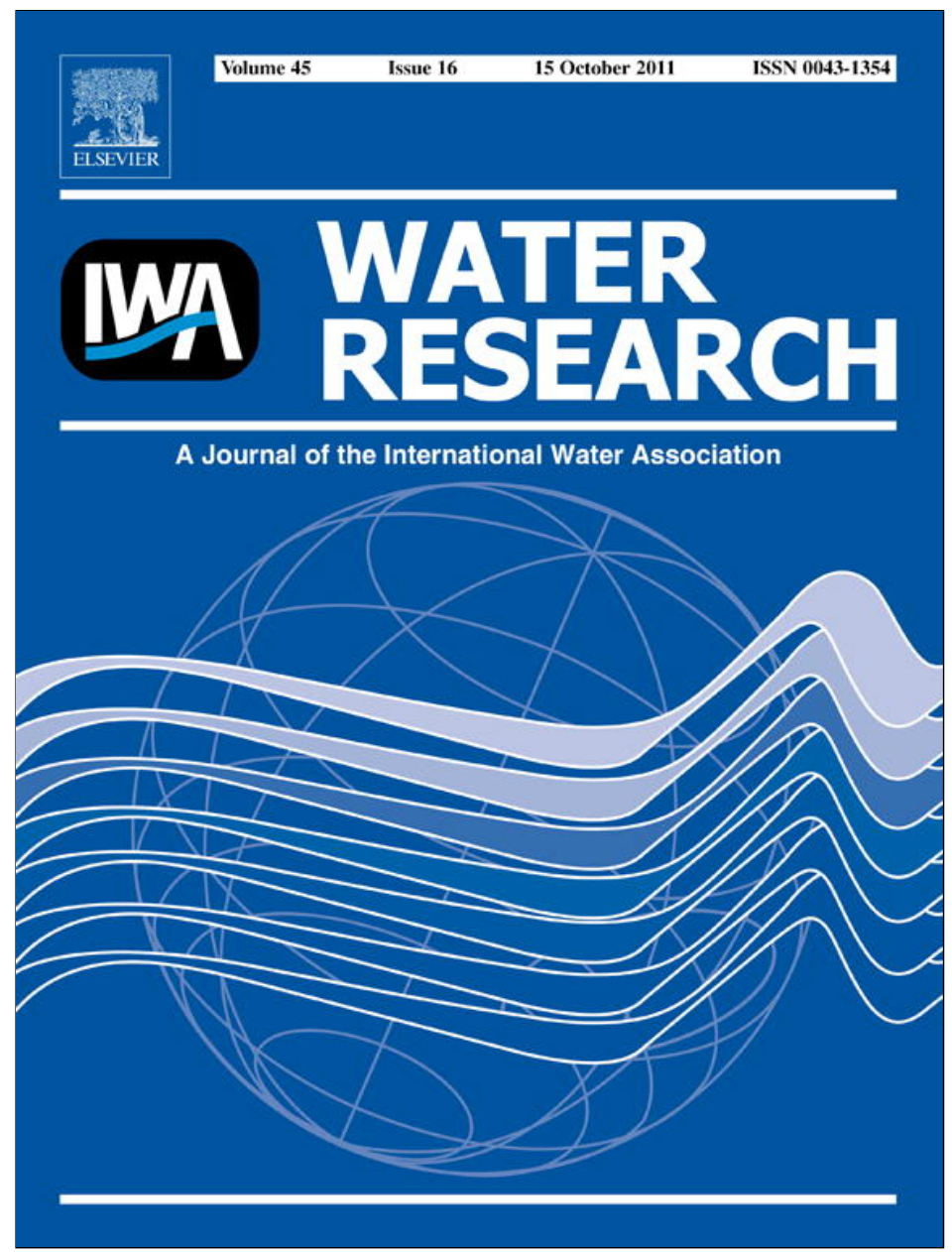

This article appeared in a journal published by Elsevier. The attached copy is furnished to the author for internal non-commercial research and education use, including for instruction at the authors institution and sharing with colleagues.

Other uses, including reproduction and distribution, or selling or licensing copies, or posting to personal, institutional or third party websites are prohibited.

In most cases authors are permitted to post their version of the article (e.g. in Word or Tex form) to their personal website or institutional repository. Authors requiring further information regarding Elsevier's archiving and manuscript policies are encouraged to visit:

http://www.elsevier.com/copyright 


\title{
Fate of the pathogen indicators phage $\Phi \times 174$ and Ascaris suum eggs during the production of struvite fertilizer from source-separated urine
}

\author{
Loïc Decrey $^{a, b}$, Kai M. Udert ${ }^{c}$, Elizabeth Tilley ${ }^{b}$, Brian M. Pecson ${ }^{a}$, Tamar Kohn ${ }^{a, *}$ \\ ${ }^{a}$ Ecole Polytechnique Fédérale de Lausanne (EPFL), Environmental Chemistry Laboratory, School of Architecture, Civil and Environmental \\ Engineering (ENAC), 1015 Lausanne, Switzerland \\ ${ }^{\mathrm{b}}$ Department of Water and Sanitation in Developing Countries, Swiss Federal Institute of Aquatic Science and Technology (Eawag), 8600 \\ Dübendorf, Switzerland \\ ${ }^{\mathrm{C}}$ Department of Process Engineering, Swiss Federal Institute of Aquatic Science and Technology (Eawag), 8600 Dübendorf, Switzerland
}

\section{A R T I C L E I N F O}

Article history:

Received 10 February 2011

Received in revised form

30 June 2011

Accepted 30 June 2011

Available online 18 July 2011

\section{Keywords:}

Struvite

Urine separation

Ascaris

Phage

Filter cake

Moisture content

\begin{abstract}
A B S T R A C T
Human urine has the potential to be a sustainable, locally and continuously available source of nutrients for agriculture. Phosphate can be efficiently recovered from human urine in the form of the mineral struvite $\left(\mathrm{MgNH}_{4} \mathrm{PO}_{4} \cdot 6 \mathrm{H}_{2} \mathrm{O}\right)$. However, struvite formation may be coupled with the precipitation of other constituents present in urine including pathogens, pharmaceuticals, and heavy metals. To determine if struvite fertilizer presents a microbiological health risk to producers and end users, we characterized the fate of a human virus surrogate (phage $\Phi \mathrm{X174}$ ) and the eggs of the helminth Ascaris suum during a low-cost struvite recovery process. While the concentration of phages was similar in both the struvite and the urine, Ascaris eggs accumulated within the solid during the precipitation and filtration process. Subsequent air-drying of the struvite filter cake partially inactivated both microorganisms; however, viable Ascaris eggs and infective phages were still detected after several days of drying. The infectivity of both viruses and eggs was affected by the specific struvite drying conditions: higher inactivation generally occurred with increased air temperature and decreased relative humidity. On a log-log scale, phage inactivation increased linearly with decreasing moisture content of the struvite, while Ascaris inactivation occurred only after achieving a minimum moisture threshold. Sunlight exposure did not directly affect the infectivity of phages or Ascaris eggs in struvite cakes, though the resultant rise in temperature accelerated the drying of the struvite cake, which contributed to inactivation.
\end{abstract}

() 2011 Elsevier Ltd. All rights reserved.

\section{Introduction}

Recovering nutrients from human excreta can help to meet fertilizer demands while simultaneously reducing the pollution of water by untreated human waste (Langergraber and Muellegger, 2005; Larsen et al., 2007). Human excreta are an especially important source of agricultural nutrients in developing countries, where the lack of affordable fertilizer is a major contributor to food shortages (Sanchez, 2002). Collecting human waste, processing it and selling the valueadded products can furthermore provide economic opportunities (Kone, 2010). Since human excreta and untreated

\footnotetext{
* Corresponding author. Tel.: +41 21693 0891; fax: +41 216938070.

E-mail address: tamar.kohn@epfl.ch (T. Kohn). 0043-1354/\$ - see front matter ( 2011 Elsevier Ltd. All rights reserved. doi:10.1016/j.watres.2011.06.042
} 
wastewater contain pathogens, pharmaceuticals and heavy metals, adequate pre-treatment is a necessity to prevent the spread of diseases and contamination (WHO, 2006; Winker et al., 2009). One efficient and simple way to harvest nutrients from human excreta is to separate the collection of urine and faeces. Most of the excreted nutrients are contained within the urine: $85-90 \%$ of nitrogen, $50-80 \%$ of phosphorus, $80-90 \%$ of potassium and close to $100 \%$ of sulphur (Larsen and Gujer, 1996). Urine of healthy people is typically sterile, but a few pathogens (e.g. Schistosoma haematobium, Salmonella typhi, Salmonella paratyphi, Leptospira interrogans) can be found in the urine of infected people (Feachem et al., 1983). In addition, feacal material, which can contain a wide range of pathogens such as bacteria, protozoa, viruses and parasitic worms (WHO, 2006), can cross-contaminate source-separated urine. This occurs particularly in the case of the misuse or the poor maintenance of urine-diverting toilets (UDTs). A Swedish study showed that 8 out of $36(22 \%)$ urine samples and 11 out of $30(37 \%)$ bottom-sedimented sludge samples taken from source-separated urine storage tanks were contaminated with feacal material (Schonning et al., 2002). In Kenya, up to 720 Ascaris eggs per litre were found in the urine of poorly maintained UDTs in a school (Kraft, 2010).

The harsh chemical conditions of stored urine, in particular the high $\mathrm{pH}$ and ammonia concentration caused by urea hydrolysis (Udert et al., 2003), promote the inactivation of microorganisms. These conditions lead to high levels of free ammonia $\left(\mathrm{NH}_{3}\right)$, a constituent known to be biocidal for most organisms (Cramer et al., 1983; Jenkins et al., 1998; Pecson and Nelson, 2005). Temperature also affects the inactivation of microorganisms in stored urine. Various studies have characterized the survival of different pathogens over a range of temperatures (Table 1).

Because of the long survival times of some pathogens at ambient temperatures, particularly viruses and helminths (Table 1), stored urine would benefit from additional treatment before being used as a fertilizer. For most applications, urine treatment is also necessary to concentrate and stabilize the nutrients or to remove micropollutants (Lienert et al.,
2007; Udert et al., 2006). Maurer et al. (2006) compiled an overview of possible technologies for urine treatment, some of which are potentially suitable for implementation in developing countries (Pronk and Kone, 2009). The majority of these technologies, however, have only been tested at lab scale.

The most studied and applied process for nutrient extraction from urine is struvite precipitation (Etter et al., 2011). Struvite $\left(\mathrm{MgNH}_{4} \mathrm{PO}_{4} \bullet 6 \mathrm{H}_{2} \mathrm{O}\right)$ is an effective phosphorus fertilizer (Romer, 2006), which can easily be produced from hydrolyzed urine. Struvite production mainly aims at recovering phosphorus from urine, since only a small percentage of the ammonia in the initial urine solution is recovered (Etter et al., 2011). Some struvite spontaneously precipitates during urine storage due to urea hydrolysis (Udert et al., 2003), though more significant quantities can be generated by adding magnesium-containing minerals. Struvite crystallization is a fast process, taking only a few minutes (Etter et al., 2011). After precipitation, struvite is usually recovered by filtration and subsequently air-dried at ambient temperatures. Struvite should not be heated above $40-55{ }^{\circ} \mathrm{C}$ due to the risk of ammonia loss, which leads to a reduction of the $\mathrm{N}$ content of the final fertilizer product (Bhuiyan et al., 2008; Frost et al., 2004). An additional step may be included to form the powder into granules that can be more easily applied as fertilizer (Etter et al., 2011).

Ronteltap et al. (2007) investigated the fate of pharmaceuticals and heavy metals during struvite production. In their experiments, only a small fraction of the spiked hormones and pharmaceuticals were incorporated into the struvite; more than $98 \%$ remained in the urine. Furthermore, struvite produced from stored urine contained significantly lower concentrations of heavy metals than commercially available fertilizers.

To date, the fate of pathogens during struvite production has not been investigated. With this study, we aim to fill this gap. In particular, we determined the survival of two commonly used and easy to manipulate surrogates of human pathogens, namely phage $\Phi \mathrm{X} 174$ as a proxy for human viruses and Ascaris suum as surrogate of the human helminth Ascaris

Table 1 - Inactivation rate of different pathogens types in (un-)diluted stored urine at pH around 9.

\begin{tabular}{|c|c|c|c|c|c|}
\hline Type & Species & $\mathrm{T}\left({ }^{\circ} \mathrm{C}\right)$ & $\begin{array}{c}\text { Dilution } \\
\text { (urine:water) }\end{array}$ & Average inactivation rate $\left(T_{90}\right)^{a}$ & Reference \\
\hline \multirow[t]{3}{*}{ Bacteria } & Enterococcus faecalis, & 34 & 1:0 & $<1$ day & (Vinneras et al., 2008) \\
\hline & Salmonella Typhimurium & 24 & & $1-2$ days & \\
\hline & & 4 & & $2-6$ days & \\
\hline \multirow[t]{5}{*}{ Viruses } & Phage $\Phi X 174$ & 34 & $1: 0$ & $<6$ days & (Vinneras et al., 2008) \\
\hline & & 24 & & 12 days & \\
\hline & & 4 & & 120 days & \\
\hline & Rotavirus & 20 & $1: 2$ & 35 days & (Hoglund et al., 2002) \\
\hline & & 5 & & NOTD $^{b}$ & \\
\hline \multirow[t]{2}{*}{ Protozoa } & Cryptosporidium & 20 & $1: 2$ & $<7$ days & (Hoglund and Stenstrom, 1999) \\
\hline & Parvum & 5 & & 29 days & \\
\hline \multirow[t]{3}{*}{ Helminths } & Ascaris suum eggs & 34 & 1:0 & 3 days $^{c}$ & (Nordin et al., 2009) \\
\hline & & 24 & & 48 days $^{c}$ & \\
\hline & & 4 & & $>480$ days $^{c}$ & \\
\hline
\end{tabular}


lumbricoides, during struvite production and drying. By using two of the most resistant pathogen classes, our goal was to provide a conservative estimate of pathogen inactivation during struvite formation. The concentrations and infectivity of these indicator organisms were measured in the precipitated struvite and during the processing of the struvite filter cake. The effect of air temperature, relative humidity (RH), sunlight exposure, and filter cake thickness was determined. The struvite production procedure was in accordance with the methods developed by Etter et al. (2011) for low-cost struvite production in Nepal.

\section{Materials and methods}

\subsection{Stored urine}

Undiluted, stored urine was obtained from the urine storage tank at Eawag's main building in Dübendorf (Switzerland), which collects urine from waterless urinals and men's NoMix toilets. The residence time of urine in the storage tank was between 37 and 47 days (Goosse et al., 2009). Urine samples were withdrawn from the tank immediately before the start of the experiments.

Throughout the duration of this study (April to October 2010), six urine samples were taken from the storage tank to assess its composition. No significant differences were observed between the samples; therefore the urine composition is presented as the average of all samples in Table 2. Phosphate, sulphate and chlorine concentrations were measured by ion chromatography (Column Metrosep A Supp 4, Metrohm, Herisau, Switzerland); magnesium, calcium, potassium and sodium by inductively coupled plasma optical emission spectrometry (ICP-OES, Ciros, Spectro Analytical Instruments, Kleve, Germany); total ammonia $\left(\mathrm{NH}_{3}+\mathrm{NH}_{4}^{+}\right)$by flow injection analysis (Application Note 5520, FOSS, Hillerød, Denmark); chemical oxygen demand (COD) with cuvette tests (Hach-Lange, Berlin, Germany) and total inorganic carbon (TIC) by means of a TOC-TN Analyser (IL 550, Hach-Lange, Berlin, Germany).

Table 2 - Average composition (at $25^{\circ} \mathrm{C}$ ) of six urine samples taken from the Eawag storage tank.

\begin{tabular}{ll} 
& Average \pm S.D. \\
\hline $\mathrm{PH}[-]$ & $8.8 \pm 0.1$ \\
$\mathrm{PO}_{4}[\mathrm{mM}]$ & $6.4 \pm 0.7$ \\
$\mathrm{NH}_{4}$ tot $[\mathrm{mM}]$ & $186 \pm 15$ \\
$\mathrm{Mg}[\mathrm{mM}]$ & $<0.5$ \\
$\mathrm{Ca}^{a}[\mathrm{mM}]$ & $0.4 \pm 0.1$ \\
$\mathrm{Cl}[\mathrm{mM}]$ & $91 \pm 10$ \\
$\mathrm{~K}[\mathrm{mM}]$ & $41 \pm 5$ \\
$\mathrm{Na}[\mathrm{mM}]$ & $83 \pm 10$ \\
$\mathrm{SO}_{4}[\mathrm{mM}]$ & $7.4 \pm 1.2$ \\
$\mathrm{TIC}^{\mathrm{a}, \mathrm{b}}[\mathrm{mM}]$ & $104 \pm 11$ \\
$\mathrm{COD}^{\mathrm{a}, \mathrm{c}}[\mathrm{mgO}$ & \\
\hline a Average of five samples. & $4684 \pm 553$ \\
b Total inorganic carbon. & \\
c Chemical oxygen demand. & \\
\hline
\end{tabular}

\subsection{Struvite production}

Struvite was produced in a batch wise operation according to the field process developed by Etter et al. (2011). Urine volumes of 1-4.5 L were stirred in a glass beaker at room temperature with a magnetic stirrer at approximately $400 \mathrm{rpm}$ and were spiked with microorganisms according to the procedure described below. Magnesium chloride hexahydrate $\left(\mathrm{MgCl}_{2} \cdot 6 \mathrm{H}_{2} \mathrm{O}\right)$ was added at a $\mathrm{Mg}$ :P molar ratio of $1: 1.1$ and mixed for $10 \mathrm{~min}$. Given an average P concentration of $6.4 \mathrm{mM}$ in the stored urine (Table 2), approximately $1.5 \mathrm{~g} \mathrm{MgCl}_{2} \bullet 6 \mathrm{H}_{2} \mathrm{O}$ was added per $\mathrm{L}$ of urine. After the magnesium addition, the urine was filtered through a nylon fabric with irregular pore diameters of $18-240 \mu \mathrm{m}$. This filter material was chosen to be consistent with the material used in a field study in Nepal (Etter et al., 2011). This allowed us to approximate the conditions of struvite production used in the field.

The discharge rate during filtration was kept as constant as possible at values ranging between 5 and $50 \mathrm{~mL} / \mathrm{min}$. At the beginning of filtration, the urine was filtered by gravity alone; later, a vacuum pump was used to maintain the same discharge rate. At the end of the filtration process, a strong vacuum was applied to maximize the drying of the struvite.

Struvite produced from $1 \mathrm{~L}$ of urine and dried under laboratory conditions $\left(23 \pm 1^{\circ} \mathrm{C}\right.$ and $\left.43 \pm 5 \% \mathrm{RH}\right)$ yielded 0.3 to $1.3 \mathrm{~g}$ of solid. The filter cakes had a diameter of $38 \mathrm{~mm}$, though its thickness varied with the volume of urine used: the average thickness of a $1 \mathrm{~L}$ cake was $1.5 \pm 0.7 \mathrm{~mm}, 2.1 \pm 0.9 \mathrm{~mm}$ for a $3 \mathrm{~L}$ cake, and $3.9 \pm 0.4 \mathrm{~mm}$ for a $4.5 \mathrm{~L}$ cake. The thickness of the cake increased from the centre to the rim.

Ascaris eggs and phages were added to the urine as indicator organisms for human pathogens prior to the struvite production (for details see Sections 2.4 and 2.5).

\subsection{Struvite cake drying experiments}

After struvite production, phage and Ascaris egg survival was monitored as a function of struvite drying under different combinations of temperature and relative humidity (Table 3). The drying conditions were set in two different ways. For the $20{ }^{\circ} \mathrm{C}$ experiments, samples were stored in temperature and humidity-controlled rooms. For the experiments at $5{ }^{\circ} \mathrm{C}$ (cold room) and $35^{\circ} \mathrm{C}$ (incubator), the samples were placed in small desiccators filled at the bottom with saturated salt solutions, as described by Winston and Bates (1960). Using $\mathrm{NaBr}$ and LiCl salts, in conjunction with water-soaked paper towels as a moisture source, a relative humidity of $85 \%$ and $35 \%$, respectively, could be maintained. Temperature and relative humidity were measured regularly with small combined thermometer/hygrometers (Piccolo, Irox, Switzerland) that were placed in the desiccators with the samples. The mean temperature and relative humidity were determined by a weighted mean of the measured data (weighted by the elapsed time between measurements). The struvite cakes were protected from light with aluminium foil during the drying phase, unless noted otherwise.

Periodic triplicate samples were taken and enumerated for infective phages and viable Ascaris eggs during three days following the production of the struvite cake (see below). This corresponds to the time frame encountered in field 
Table 3 - List of the experimental parameters tested for phage $\Phi$ X174 ( $\Phi$ ) and Ascaris suum eggs (A).

\begin{tabular}{lcccccc} 
No. & Shade/Sun & Temperature & Relative humidity & Urine filtered & Day of sampling & Microorganisms spiked \\
\hline A & Shade & $5^{\circ} \mathrm{C}( \pm 0)$ & $35 \%( \pm 9)$ & $1 \mathrm{~L}$ & $0,1,3,10$ & $\Phi$ \\
B & Shade & $5^{\circ} \mathrm{C}( \pm 0)$ & $85 \%( \pm 3)$ & $1 \mathrm{~L}$ & $0,1,2,3,10^{\mathrm{a}}$ & $\Phi, \mathrm{A}$ \\
C & Shade & $20^{\circ} \mathrm{C}( \pm 0)$ & $42 \%( \pm 2)$ & $1 \mathrm{~L}$ & $0,1,2,3$ & $\Phi, \mathrm{A}$ \\
D.1 & Shade & $20^{\circ} \mathrm{C}( \pm 0)$ & $77 \%( \pm 4)$ & $1 \mathrm{~L}$ & $0,1,2,3$ & $\Phi, \mathrm{A}$ \\
D.2 & Shade & $20^{\circ} \mathrm{C}( \pm 0)$ & $77 \%( \pm 4)$ & $3 \mathrm{~L}$ & $0,1,2,3$ & $\Phi$ \\
E.1 & Shade & $20^{\circ} \mathrm{C}( \pm 0)$ & $90 \%( \pm 0)$ & $1 \mathrm{~L}$ & $0,1,2,3$ & $\Phi, \mathrm{A}$ \\
E.2 & Shade & $20^{\circ} \mathrm{C}( \pm 0)$ & $93 \%( \pm 1)$ & $1 \mathrm{~L}$ & $0,1,2,3$ & $\Phi$ \\
E.3 & Shade & $20^{\circ} \mathrm{C}( \pm 0)$ & $93 \%( \pm 1)$ & $3 \mathrm{~L}$ & $0,1,2,3$ & $\Phi$ \\
E.4 & Shade & $20^{\circ} \mathrm{C}( \pm 0)$ & $93 \%( \pm 1)$ & $1 \mathrm{~L}$ & $0,1,2,3,9$ & $\Phi$ \\
E.5 & Shade & $20^{\circ} \mathrm{C}( \pm 0)$ & $93 \%( \pm 1)$ & $4.5 \mathrm{~L}$ & $0,1,2,3,9$ & $\Phi, \mathrm{A}$ \\
F & Shade & $36^{\circ} \mathrm{C}( \pm 1)$ & $36 \%( \pm 8)$ & $1 \mathrm{~L}$ & $0,6 \mathrm{~h}, 1,3$ & $\Phi, \mathrm{A}$ \\
G & Shade & $35^{\circ} \mathrm{C}( \pm 1)$ & $85 \%( \pm 3)$ & $1 \mathrm{~L}$ & $0,1,2,3$ & $\Phi, \mathrm{A}$ \\
$\mathrm{H}$ & Sun & $31^{\circ} \mathrm{C}( \pm 3)$ & $<35 \%$ & $1 \mathrm{~L}$ & $0,1 \mathrm{~h}, 2 \mathrm{~h}, 5 \mathrm{~h}$ & \\
\hline
\end{tabular}

experiments, where the struvite is dried for two to three days in between filtration and further processing (Etter et al., 2011). In addition, we conducted experiments to assess the inactivation of phages during longer drying periods (9-10 days).

\subsection{Phage enumeration}

ФX174 (ATCC 13706-B1) and their host Escherichia coli (ATCC 13706) were purchased from the German Collection of Microorganisms and Cell Cultures (DSMZ, Braunschweig, Germany). Phages were propagated in liquid culture according to DSMZ instructions, and were enumerated by the double layer agar method. Infective phage numbers are reported in plaque forming units (pfu). A phage stock solution of approximately $10^{9} \mathrm{pfu} / \mathrm{mL}$ was produced, passed through $0.45 \mu \mathrm{m}$ pore size filters to remove bacterial debris, inoculated with streptomycin (final concentration $2 \mathrm{mg} / \mathrm{L}$ ) to prevent further bacterial growth and stored at $4{ }^{\circ} \mathrm{C} .10 \mathrm{~mL}$ of this concentrated stock were spiked into $1 \mathrm{~L}$ of stored urine to achieve an initial concentration of $10^{6}-10^{7} \mathrm{pfu} / \mathrm{mL}$ of urine.

Phage concentrations were determined in the struvite filter influent, effluent and in the struvite filter cake. Prior to enumeration, samples were diluted in phosphate buffered saline (PBS; $5 \mathrm{mM} \mathrm{NaH} \mathrm{PO}_{4} \bullet \mathrm{H}_{2} \mathrm{O}, 10 \mathrm{mM} \mathrm{NaCl}$ ) at $\mathrm{pH}$ 7.5. For the enumeration of phages in the influent and effluent, samples were directly diluted by PBS and plated. For the enumeration of phages in struvite, 50-100 mg of struvite were carefully removed from the filter cake in small pieces ranging from the centre to the rim, dissolved in $1 \mathrm{~mL}$ citrate buffer $\left(41.5 \mathrm{mM} \mathrm{C}_{6} \mathrm{H}_{5} \mathrm{Na}_{3} \mathrm{O}_{7} \bullet 2 \mathrm{H}_{2} \mathrm{O}, 9.5 \mathrm{mM} \mathrm{C}_{6} \mathrm{H}_{8} \mathrm{O}_{7} \bullet \mathrm{H}_{2} \mathrm{O}, 10 \mathrm{mM} \mathrm{NaCl}\right)$ at pH 5.7 by vortexing during $30 \mathrm{~s}$, further diluted in PBS, and plated. Control experiments confirmed that this process recovered all the phages from the struvite, that the phages did not replicate or aggregate in stored urine, and that they were not inactivated in the citrate buffer.

Phage inactivation is expressed in terms of concentration of infective phage over initial concentration of infective phage $\left(\mathrm{C} / \mathrm{C}_{0}\right)$ throughout the study.

\subsection{Ascaris suum enumeration}

A stock of $10^{6}$ Ascaris eggs (Excelsior Sentinel Inc., Ithaca, $\mathrm{NY}$ ) stored at $4^{\circ} \mathrm{C}$ in $0.5 \%$ formalin, was used to obtain a homogeneous spiking solution containing approximately $10^{4}$ eggs/mL by stirring $2 \mathrm{~mL}$ into $8 \mathrm{~mL}$ of milliQ water. The resulting exact concentration was determined from three samples of $150 \mu \mathrm{L}$ enumerated under a microscope using worm egg counting slide (McMaster, JA Whitlock \& Co, Australia). One $\mathrm{mL}$ of the spiking solution was then transferred into $0.5 \mathrm{~L}$ of urine, which was subsequently processed to produce struvite. Control experiments determined the ratio of eggs adhering to the walls of the beaker and the struvite filter setup (described in the Supplementary information), to derive the actual number of eggs suspended in the urine in relation to the number of eggs initially added with the spiking solution.

Eggs in the struvite were enumerated by dissolving 50-100 mg of struvite in $1 \mathrm{~mL}$ of $0.1 \mathrm{M} \mathrm{H}_{2} \mathrm{SO}_{4}$ and counting the eggs in $3 \times 150 \mu \mathrm{L}$ of this solution as described above. The egg numbers were extrapolated to $1 \mathrm{~mL}$ to determine the egg concentration in the struvite cake.

The viability of the eggs in struvite was assessed by mixing 50-100 mg of the struvite filter cake produced from $1 \mathrm{~L}$ stored urine with $1 \mathrm{~mL}$ of $0.1 \mathrm{M} \mathrm{H}_{2} \mathrm{SO}_{4}$. This solution was centrifuged at $4000 \mathrm{rpm}$ for $3 \mathrm{~min}$ to sediment the eggs and the supernatant was removed and replaced by new sulphuric acid. This process was carried out five times to dissolve the struvite, and to lower the $\mathrm{pH}$ to around 2 to avoid microbial growth to prevent the formation of free ammonia (100 mg struvite/ml corresponds to approximately $400 \mathrm{mM}$ total ammonia) during the subsequent incubation. The sedimented eggs were incubated in the dark in uncapped tubes for 4 weeks at $28^{\circ} \mathrm{C}$ (Pecson and Nelson, 2005). After incubation, a solution aliquot was examined under a microscope (magnification 10x and $40 \mathrm{x})$ to assess the viability of 200 eggs. Only eggs that had developed to the full larval stage were counted as viable.

Ascaris egg inactivation is expressed in terms of measured concentration of viable eggs over initial concentration of viable eggs $\left(C / C_{0}\right)$ throughout the study.

\subsection{Drying curve and moisture content of struvite}

To assess the cake's moisture content during drying, unspiked struvite cakes were produced and dried at the same time and under the same conditions as the ones spiked with 
microorganisms. The loss of mass from these cakes over time was monitored with a digital balance to obtain a drying curve.

The microorganism concentrations in and the moisture content of a wet solid (e.g. sludge) are generally expressed in units per mass of dry material. However, struvite undergoes thermal decomposition starting at $40-55^{\circ} \mathrm{C}$ due to the volatilization of water and ammonia bound in the struvite crystals (Bhuiyan et al., 2008; Frost et al., 2004); therefore the exact dry mass could not be determined by heating the samples. Instead, struvite cakes were allowed to dry until they reached mass equilibrium $\left(m_{e}\right)$ under the targeted temperature and relative humidity conditions. Subsequently, the cakes were dried under reference laboratory conditions $\left(23 \pm 1{ }^{\circ} \mathrm{C}\right.$ and $43 \pm 5 \% \mathrm{RH})$ until no further mass change was observed $\left(m_{\text {ref }}\right)$. The gravimetric moisture content $\left(\theta_{g} ;[g / g]\right)$ of the cake at any time during the drying process was related to $m_{\text {ref }}$ by the following relationship, which can be interpreted as the mass of moisture available for evaporation over mass of the cake at equilibrium under reference conditions:

$\theta_{g}(t)=\frac{m_{t}-m_{\text {ref }}}{m_{\text {ref }}}$

where $m_{t}$ is the mass of the cake at time t. $10-15 \%$ of $m_{\text {ref }}$ or 0.11-0.18 g moisture/g dry mass, was determined to be remaining moisture (see last paragraph in this section for methodology).

In order to compare the different drying curves, the moisture ratio $\theta_{g} / \theta_{g 0}$ was plotted against time, where $\theta_{g 0}$ is the moisture content at the beginning of the drying process $(t=0)$.

Similarly, the concentration of surviving microorganisms (C; [pfu/g] or [viable eggs/g]) was normalized to the laboratorydried struvite mass $m_{\text {ref }}$ as follows:

$C_{t}=C_{t_{\text {-measured }}} \frac{m_{t}}{m_{\text {ref }}}$

where $C_{t}$ is the normalized concentration of the microorganisms at time $t$; and $C_{t}$ measured is the actual concentration measured at time $t$ for a mass $m_{t}$.

In order to express the drying of the cakes as a function of time, we used the Lewis thin layer drying model to fit our data (Lewis, 1921; Panchariya et al., 2002):

$\frac{m_{\mathrm{t}}-m_{e}}{m_{0}-m_{e}}=\exp \left(-k_{0} t\right)$

where $k_{\circ}[1 /$ time] is an empirical parameter determined by an exponential fit. Drying curves from experiments A, B, F, G, H (Table 3) were fitted with the Lewis equation yielding an $R^{2}$ value between 0.96 and 0.99 . The balance precision was $1 \mathrm{mg}$, therefore moisture contents lower than $0.001 \mathrm{~g} / \mathrm{g}$ were extrapolated from Equations (1) and (3) using the respective fitted drying curve derived for each experiment. Data for which the moisture content was estimated by fitting are indicated by an asterisk in Figs. 3 and 5. The mass of liquid in the wet filter fabric was considered negligible in our calculations.

The typical moisture content in struvite cakes after drying under laboratory conditions was determined in 2 cakes made from $1 \mathrm{~L}$ of urine. Around $0.5 \mathrm{~g}$ of the cake was dissolved in $100 \mathrm{~mL} 1 \mathrm{M} \mathrm{HCl}$, and the phosphorus and magnesium concentrations were determined. These concentrations were used to calculate the mass of struvite in the filter cake, from which the remaining moisture content was then determined.

\subsection{Sunlight experiments}

Filter cakes were exposed to natural sunlight for $5 \mathrm{~h}$ (12:00 to 17:00) under a clear sky on 20 July, 2010, on the roof of the Eawag laboratory building $\left(47^{\circ} 23^{\prime} \mathrm{N}, 8^{\circ} 37^{\prime} \mathrm{E}\right)$. Struvite filter cakes were placed in a glass beaker, the bottom of which was covered with cloth to prevent the samples from getting wet from any condensation that may have formed on the surface of the glass. The beaker was placed in a plastic bucket filled with ice in order to maintain the temperature in and around the filter cakes close to $30^{\circ} \mathrm{C}$ (Table 3 , experiment $\mathrm{H}$ ). The parts of the setup that did not need to be exposed to the sunlight were covered with aluminium foil to slow the melting of the ice. The air temperature was measured with a PT100 sensor (TST310, Endress + Hauser, Reinach, Switzerland) set next to the filter cake and connected to a data logger with a resolution of one measurement per minute. We were not able to measure the relative humidity just above the glass beaker during the experiment; however, by comparing the drying curve of the sunlight-exposed cake to those obtained in the experiments at $35^{\circ} \mathrm{C}$ in the shade inside the laboratory, we can conclude that the relative humidity was lower than $35 \%$.

The cumulative radiant exposure (fluence over the range of 280-900 nm) throughout the experiment was calculated from periodic irradiance measurements obtained by means of a spectroradiometer (model ILT-900-R; International Light). After 1, 2 and $5 \mathrm{~h}$, fluences of 2119, 3974 and $7953 \mathrm{~kJ} / \mathrm{m}^{2}$ were determined, respectively.

\section{8. $\mathrm{NH}_{3}$ concentration}

$\mathrm{NH}_{3}$ concentration, $\mathrm{pH}$ and ionic strength in the cake moisture during drying were estimated for the conditions exhibiting the highest inactivation rates $\left(36^{\circ} \mathrm{C} / 36 \% \mathrm{RH}\right.$, see Figs. $2 \mathrm{a}$ and $\left.5 \mathrm{a}\right)$. Besides the evaporation of water and volatilization of $\mathrm{NH}_{3}$, the loss of $\mathrm{CO}_{2}$ was also considered because of its effect on $\mathrm{pH}$ and ionic strength of the solution. Assuming that the loss of water, $\mathrm{NH}_{3}$ and $\mathrm{CO}_{2}$ were limited by the diffusion out of small airfilled pores, which act as bottleneck boundaries, we used the film model to approximate the gas exchange (Schwarzenbach et al., 2003) (see Supplementary information).

The simulation of the $\mathrm{NH}_{3}$ concentration, $\mathrm{pH}$ and ionic strength was performed by first calculating the composition of the moisture based on Table 2 (especially $\mathrm{NH}_{3}$ and $\mathrm{CO}_{2}$ concentration) with the computer code EQ3/6 Version 8.0 (Wolery and Jarek, 2003). This code allows calculating the chemical speciation in high-strength solutions, using the Pitzer approach for ionic strength corrections. The computer code was enhanced with equilibrium constants and Pitzer parameters for the dominant phosphate complexes (Supplementary information). The solubility constant for struvite and its temperature dependency was taken from Ronteltap et al. (2007). More details about the extension of the computer code are given in the Supplementary information. Simulations were performed stepwise and the concentrations were corrected according to an estimated gas exchange (for details, see Supplementary information). 
For the sake of consistency, EQ3/6 was also used to recalculate the $\mathrm{NH}_{3}$ concentrations in the experiments of other authors cited herein.

\section{Results and discussions}

\subsection{Phage $\Phi \times 174$ distribution}

Fig. 1a shows the distribution of phages between urine influent and struvite for different initial phage concentrations and different volumes of urine. The absolute number of phages in struvite was $3 \log _{10}$ units (1000-fold) lower than the initial number in the urine (Fig. 1a). This was the case for every volume of urine and initial phage number tested. When comparing phage concentrations on a struvite mass basis, assuming a urine density of $1.02 \mathrm{~g} / \mathrm{cm}^{3}$ (Price et al., 1940), the values were approximately equal for urine and struvite (Fig. 1a). As the moisture content of the cake immediately after filtration was rather high, $(1.81 \pm 0.30 \mathrm{~g}$ moisture/g dry mass, $1.29 \pm 0.11 \mathrm{~g} / \mathrm{g}$ and $1.25 \mathrm{~g} / \mathrm{g}$ for the cake made from $1 \mathrm{~L}$, $3 \mathrm{~L}$ and $4.5 \mathrm{~L}$ respectively) the concentration of phages in the struvite cake can be mainly attributed to the presence of phages in the residual urine contained by the cake. The even distribution of the phage concentration between urine and struvite suggests that neither straining by the filter fabric and filter cake, nor phage adsorption onto struvite, occurred during the filtration process. The apparent lack of straining can be explained by the very small size of $\Phi$ X174 $(27 \mathrm{~nm}$ diameter (Dowd et al., 1998)). The absence of phage adsorption can be explained by considering the electrostatic interactions between struvite and phages. It has been shown that struvite particles are negatively charged in struvite-saturated solutions $(10 \mathrm{mM} \mathrm{NaCl}$ ) at $\mathrm{pH}$ 9.0-10.0 (Bouropoulos and Koutsoukos, 2000). In the same study, it was shown that an increase in the $\mathrm{Mg}^{2+}$ bulk concentrations reduced the negative surface charge, eventually resulting in a positive charge, if $\mathrm{Mg}^{2+}$ concentrations were above $18 \mathrm{mM}$. In our experiments, less than $1 \mathrm{mM}$ of $\mathrm{Mg}^{2+}$ remained in solution after struvite precipitation (data not shown). Other, mostly monovalent cations $\left(\mathrm{Na}^{+}, \mathrm{K}^{+}\right.$; Table 2$)$, may have additionally shielded the negative charge of the struvite. Nevertheless, we assume that struvite was negatively charged under the conditions of our experiment. $\Phi \times 174$ also carries a negative surface charge under alkaline conditions, since its isoelectric point (PI) is 6.6 (Michen and Graule, 2010). This implies that there was electrostatic repulsion between struvite and phages.

Although adsorption was not predominant under the conditions of our experiments, it may have a more pronounced effect on viruses with a pI higher than $\Phi \mathrm{X} 174$. However, only few viruses have been reported to have a pI greater than 7. Examples among those with a high pI are

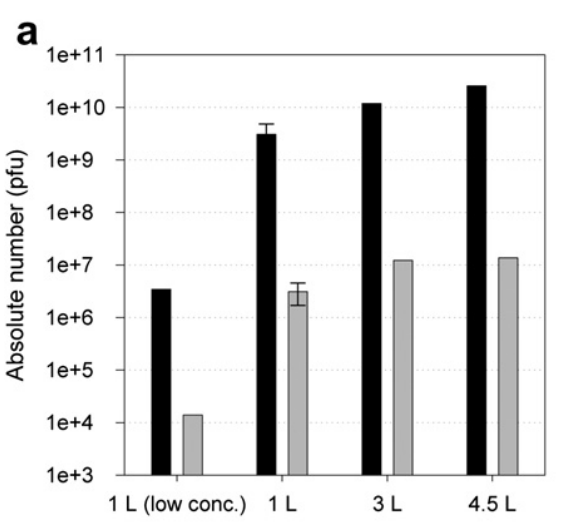

\section{ФX174}

b

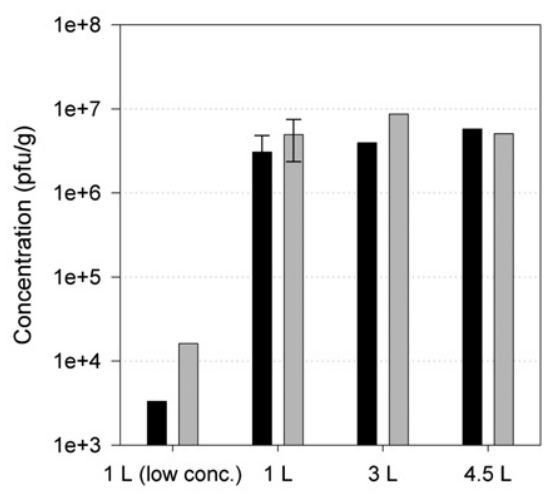

Ascaris suum
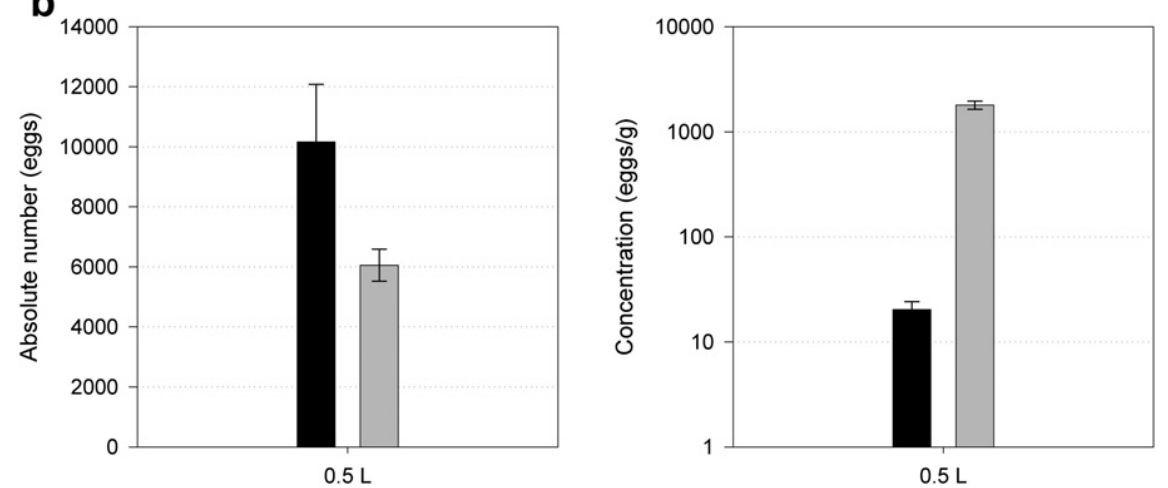

Fig. 1 - Distribution of $\Phi \times 174$ and Ascaris eggs between urine and struvite. Absolute number (left) and concentration of (a) $\Phi \times 174$ and (b) Ascaris eggs in urine influent (black) and struvite filter cake (grey). Error bars depict standard deviation for experiments with 3 or more replicates. Number of experiments with $\Phi X 174: 2$ (1 L, low conc.), 9 (1 L), 2 (3 L) and 1 (4.5 L). 3

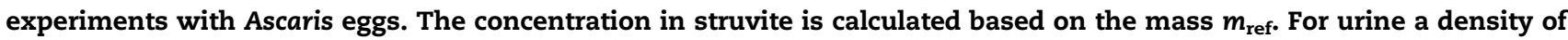
$1.02 \mathrm{~g} / \mathrm{cm}^{3}$ was used (Price et al., 1940). 
poliovirus and rotavirus (Michen and Graule, 2010). These two viruses could thus be expected to be retained by struvite more strongly than the viruses investigated herein. In addition, solutions with higher amounts of $\mathrm{Mg}^{2+}$ resulting from a higher $\mathrm{Mg}^{2+}$ dosage could lead to more adsorption of viruses with low pI onto struvite. Dosages of up to $1.8 \mathrm{~mol} \mathrm{Mg} / \mathrm{mol}$ P were used to achieve more than 95\% phosphorus recovery (Abegglen, 2008). For stored urine with a phosphorus content similar to our experiments (Table 2), the remaining $\mathrm{Mg}^{2+}$ concentration upon addition of this higher dosage would be as low as $5.5 \mathrm{mM}$ after precipitation. This is considerably lower than the $18 \mathrm{mM}$ that were reported for a neutral surface charge of struvite (Bouropoulos and Koutsoukos, 2000).

Finally, it should be noted that the measured phage concentrations in the filter effluent were of the same order of magnitude as the concentrations measured in the influent. This indicates that no considerable inactivation took place during the mixing and the filtration step.

\subsection{Ascaris egg distribution}

Of the eggs initially added to the influent urine, 10-15\% were found to adhere to the beaker and the filter setup, 50-55\% were retained by the struvite cake, and the remainder broke through into in the effluent. This resulted in a 100-fold higher concentration of Ascaris eggs in struvite compared to the influent urine (Fig. 1b). Thus, the retention of Ascaris eggs on the filter and in the filter cake was high but incomplete. Ascaris eggs, which have a size of $35-50 \times 45-70 \mu \mathrm{m}$ (Jensen et al., 2009), are similar in size to the filter pore size. This led to partial straining of the eggs (around $60 \%$ of the suspended fraction) by the filter and the filter cake as soon as the struvite cake started to form.

There were no significant changes in the Ascaris egg viability in the control or in the struvite immediately after filtration (data not shown); the mixing and filtration steps therefore had no effect on the survival of the eggs.

\subsection{Phage $\Phi \times 174$ inactivation during drying phase}

\subsubsection{Effect of temperature and relative humidity}

Phages in filter cakes made from $1 \mathrm{~L}$ of stored urine were dried at different combinations of temperature and relative humidity. The concentration of surviving phages was regularly enumerated over the course of several days. A decrease in infective phage concentrations was observed in all experiments (Fig. 2), though the degree of inactivation depended on the environmental conditions. To assess the reproducibility of the experiments, experiments at $20{ }^{\circ} \mathrm{C} / 90 \% \mathrm{RH}$ were performed in triplicate. The maximum variation in phage concentration between replicates was $0.5-0.8 \log _{10}$ units at each sampling point (Fig. 2c).

Inactivation during struvite drying was fastest at high temperatures and low relative humidity and slowest at low temperature and high relative humidity. After 3 days of drying, inactivation spanned a range of $0.5 \log _{10}$ units at $5{ }^{\circ} \mathrm{C} /$ $85 \% \mathrm{RH}$ to $3.5 \log _{10}$ units at $36^{\circ} \mathrm{C} / 35 \% \mathrm{RH}$ (Fig. 2). Inactivation rates gradually decreased over the course of 3 days (Fig. 2). Samples taken after 9 and 10 days confirmed this tendency (data not shown): a reduction of $0.03,0.07$ and $0.09 \log _{10} /$ day was observed for drying times longer than three days at $5{ }^{\circ} \mathrm{C} /$ $85 \%, 20{ }^{\circ} \mathrm{C} / 93 \%$ and $5{ }^{\circ} \mathrm{C} / 35 \%$ respectively.

Temperature variations showed a large effect on the inactivation curves at both low (Fig. 2a) and high relative humidity (Fig. 2b). The effect of relative humidity on the inactivation was less pronounced, yet also apparent (Fig. 2c). The observed phage inactivation was thus a combination of the effects of temperature and relative humidity. As temperature and relative humidity both influence the moisture content of the cake $\left(\theta_{g}\right.$; see Section 2.6, Equation (1)), we examined whether this parameter correlated with the inactivation of the organisms tested. Within a $3 \log _{10}$ decrease of the moisture content of the cake, a linear relationship between the logarithms of moisture content and inactivation was found from filtration experiment using $1 \mathrm{~L}$ of urine (Fig. 3a). From this relationship, a dependency of virus inactivation on moisture of $0.61 \pm 0.042 \log _{10}$ viruses inactivated $\left(\log C / C_{0}\right)$ per $\log _{10}$ of moisture content $\left(\log \theta_{g}\right.$ ) was determined (robust regression with bisquare weighting function, MATLAB; error indicates the $95 \%$ confidence interval). In other words, when the moisture content was reduced by $90 \%, 75 \%$ of the phages were inactivated.

A correlation between virus inactivation and decreasing moisture content was also observed for poliovirus in soil (Yeager and Obrien, 1979), in sludge (Brashear and Ward, 1983; Ward and Ashley, 1977b) and poliovirus and coliphages (MS2, PRD1) in soil amended with sludge (Straub et al., 1992). Although none of the authors compared inactivation and moisture content on a log-log scale, their data suggest a logarithmic dependency. Notably, our experiments showed the same correlation of inactivation and moisture content independent of the temperature or relative humidity (Fig. 3a). This correlation can thus be used to predict inactivation over a wide range of environmental conditions. Similarly, Straub et al. (1992) observed a correlation between soil moisture and phages (MS2 and PRD1) inactivation which was independent of the drying temperature over a range of $15-40^{\circ} \mathrm{C}$.

In addition to the direct effect of water evaporation, possibly leading to inactivation by desiccation, the loss of moisture from the filter cake could result in inactivation for three other reasons: the formation of a solid-air-water interface, the change in $\mathrm{pH}$ and $\mathrm{NH}_{3}$ concentration, and the increase in ionic strength (i.e. osmotic pressure). Dewatering leads to the introduction of air and the creation of a solidwater-air interface within the struvite cake. Thompson and Yates (1999) showed that if viruses in a solution containing Teflon beads were mixed with air, virus inactivation occurred. This effect, however, was only observed for hydrophobic surfaces in combination with phage MS2, which is known to be more hydrophobic than $\Phi X 174$ (Shields and Farrah, 2002). $\Phi \times 174$, in contrast, was not susceptible to this type of inactivation. Therefore, we do not expect that the solid-air-water interface had an effect on inactivation in our experiments.

Secondly, the chemical composition of urine may cause inactivation due to the high $\mathrm{pH}$ and $\mathrm{NH}_{3}$ content, both of which have been shown to have virucidal properties (Cramer et al., 1983; Ward and Ashley, 1977a). The $\mathrm{NH}_{3}$ fraction of total ammonia $\left(\mathrm{NH}_{3}+\mathrm{NH}_{4}^{+}\right.$) increases with rising $\mathrm{pH}$ and rising temperature. For $\Phi X 174$, Vinneras et al. (2008) observed a $1 \log _{10}$ inactivation after 5.7, 12 and 120 days at 34, 24 and 

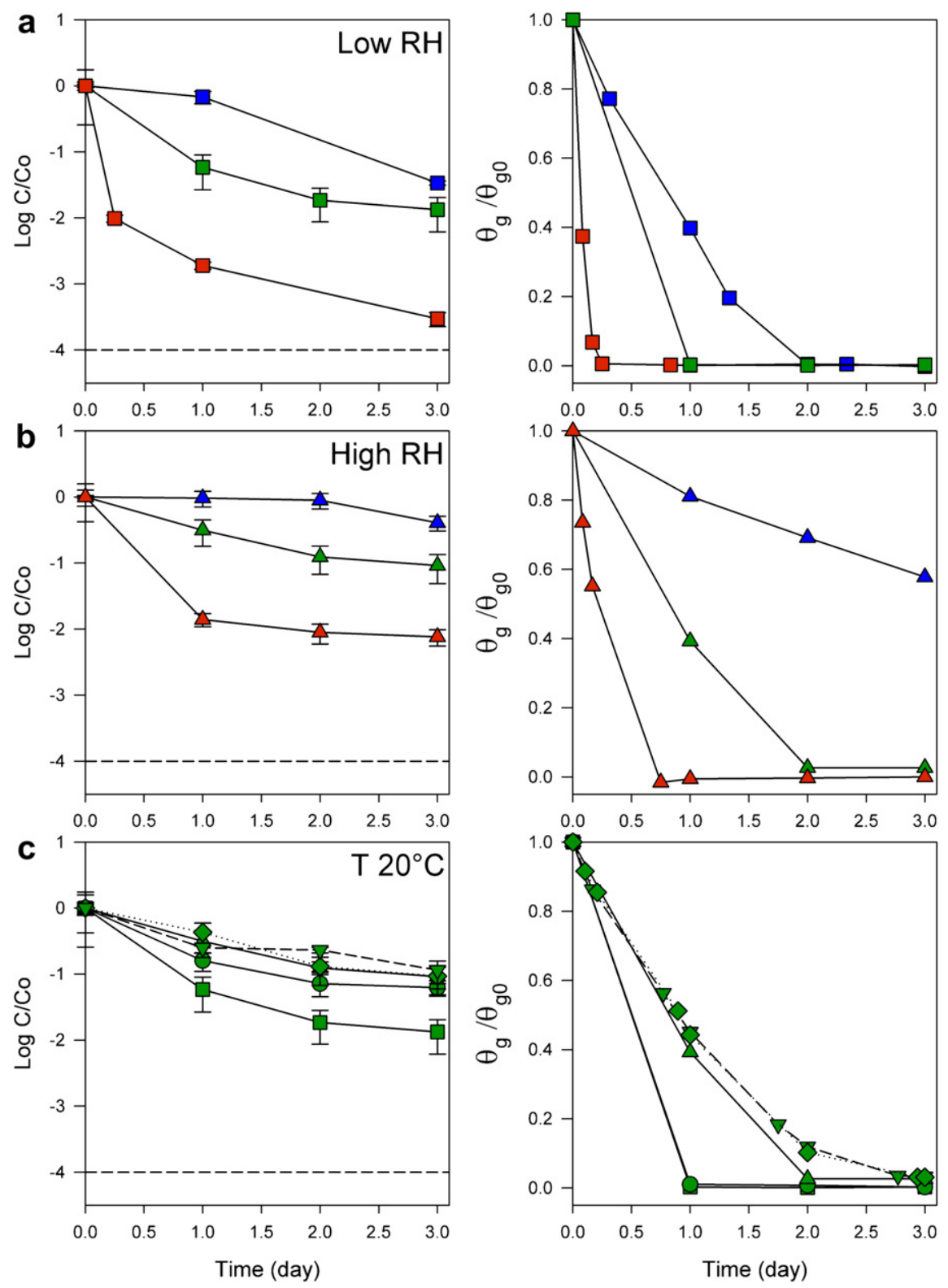

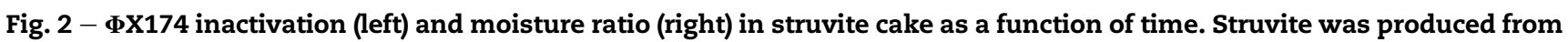
$1 \mathrm{~L}$ of stored urine. Drying conditions: (a) Low RH (35-42\%) and variable T (5 ${ }^{\circ} \mathrm{C}(\square), 20^{\circ} \mathrm{C}(\square)$ and $36^{\circ} \mathrm{C}$ ( $\left.\square\right)$. (b) High RH (85-93\%) and variable $T\left(5^{\circ} \mathrm{C}(\Delta), 20^{\circ} \mathrm{C}(\Delta)\right.$ and $\left.35^{\circ} \mathrm{C}(\Delta)\right)$. (c) Constant $\mathrm{T}\left(20^{\circ} \mathrm{C}\right)$ and variable $\mathrm{RH}(42 \%(\square), 77 \%(\bullet)$ and $90-93 \%$ $(\Delta[E .1],-[E .2], \nabla$ [E.4]; see Table 3). The dashed line $(-)$ indicates the detection limit. Error bars depict standard deviation of triplicate enumeration of the same sample.

$4{ }^{\circ} \mathrm{C}$, respectively, in urine containing $426 \mathrm{mM}$ total ammonia $\left(164,102\right.$ and $\left.34 \mathrm{mM} \mathrm{NH}_{3}\right)$. In our experiments, we measured up to $95 \%$ moisture content reduction in the cake during drying. On this basis, an approximation of the $\mathrm{NH}_{3}$ concentration in the cake moisture was simulated for the conditions with the highest inactivation rate $\left(36^{\circ} \mathrm{C} / 36 \% \mathrm{RH}\right)$. Fig. 4 shows that the $\mathrm{NH}_{3}$ concentration, which was initially around $80 \mathrm{mmol} / \mathrm{kg}_{\text {water }}(\sim 80 \mathrm{mM})$ decreased with decreasing moisture content and stabilized below $1 \mathrm{mmol} / \mathrm{kg}_{\text {water }}$ after a moisture content reduction of $20 \%$, corresponding to $30 \mathrm{~min}$ of drying. Despite this low $\mathrm{NH}_{3}$ concentration we measured a much higher inactivation rate than Vinneras et al. (2008).
Therefore, we do not expect that the $\mathrm{NH}_{3}$ caused inactivation in our experiments. The $\mathrm{pH}$ exhibited a similar dependence on moisture content. From its initial value of around 9, the $\mathrm{pH}$ rapidly decreased to approximately 6.7 within the first $20 \%$ of moisture loss. Additional drying caused only a small further decreased in $\mathrm{pH}$ (Fig. 4). $\mathrm{pH}$ values in the neutral range are not virucidal (Feng et al., 2003). We therefore conclude that the change in moisture $\mathrm{pH}$ did not contribute to inactivation. Finally, it has been shown that high ionic strength up to $2 \mathrm{M}$ does not affect the inactivation of $\Phi \times 174$ (Thompson and Yates, 1999). In our experiments, the estimated ionic strength upon drying of the struvite cake reached around $2 \mathrm{M}$ 

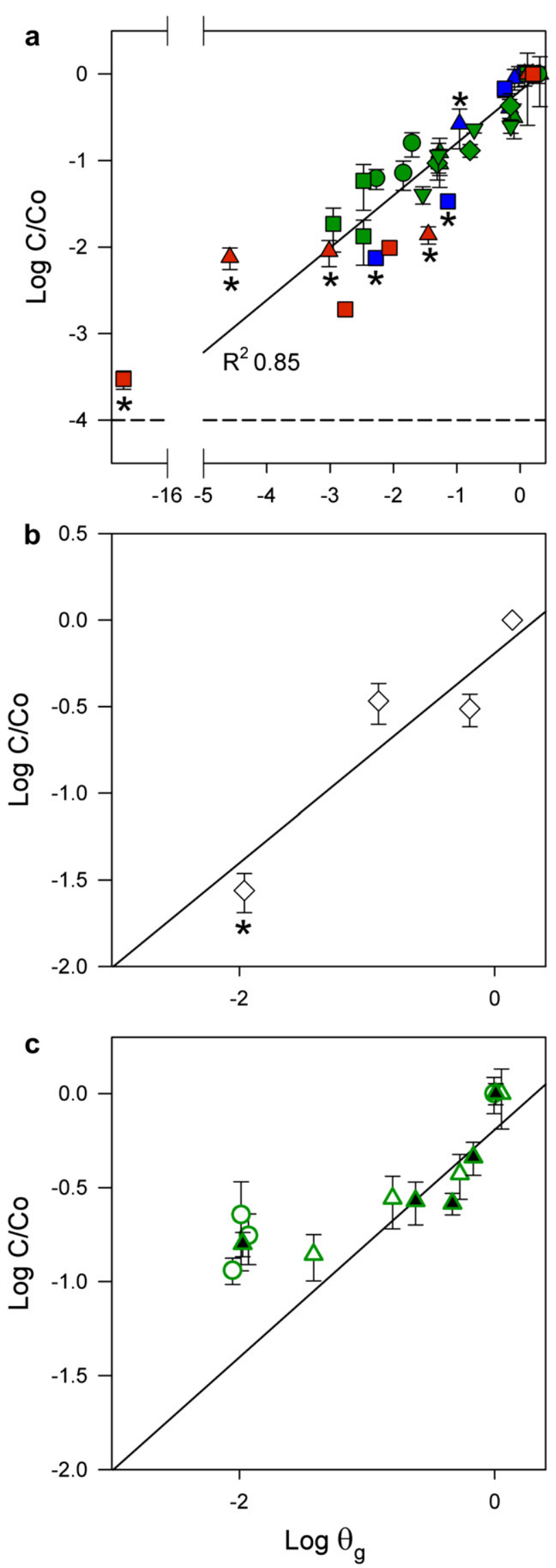

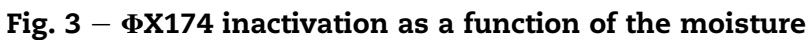
content of the cake $\left(\theta_{\mathrm{g}}\right)$ : (a) comparison between filter cake for the experiment at $36^{\circ} \mathrm{C} / 36 \%$ RH (Fig. 4). Therefore we can infer that inactivation remains unaffected by ionic strength.

In summary, neither the solid-air-water interface, the $\mathrm{NH}_{3}$ concentration, the $\mathrm{pH}$, nor the increase in ionic strength was likely to account for the observed phage inactivation. Thus, desiccation remains the best parameter for rationalizing the observed relationship between the moisture content and phage inactivation. The moisture content therefore remains the best parameter to predict the level of inactivation at the filter cake size of our experiments $(1.5 \pm 0.7 \mathrm{~mm}$ thickness). Thus, within the temperature range $\left(5-36{ }^{\circ} \mathrm{C}\right)$, relative humidity range (35-93\%) and time scale (0-10 days) of our experiments, temperature and relative humidity should be seen as parameters that influence the phage inactivation rate by determining the moisture evaporation rate. Since the moisture content nearly reached its equilibrium value after three days (Fig. 2), and since higher temperatures and lower relative humidity led to lower moisture content and lower concentrations of infective viruses (Fig. 3), increasing the temperature or reducing relative humidity was more effective for pathogen inactivation than increasing the drying time.

\subsubsection{Effect of sunlight}

Phages are known to be susceptible to direct inactivation by sunlight in the UVB range, as well as to indirect inactivation by higher wavelengths (Davies-Colley et al., 2000). \$X174 was shown to be one of the most sensitive viruses to sunlight irradiation among bacteriophages and human viruses (Hijnen et al., 2006; Love et al., 2010). If this phage is not inactivated, more resistant viruses will not be affected either. To test if the presence of sunlight enhances phage inactivation during struvite drying, experiments were conducted under solar irradiation (experiment $\mathrm{H}$, Table 3 ) and the resulting inactivation was compared to control experiments in the dark. After $5 \mathrm{~h}$ of exposure to natural sunlight $\left(7953 \mathrm{~kJ} / \mathrm{m}^{2}, 31{ }^{\circ} \mathrm{C}\right.$, $\mathrm{RH}<35 \%$ ), a $1.5 \log _{10}$ inactivation was observed (data not shown), while after $6 \mathrm{~h}$ in the shade under similar experimental conditions $\left(36^{\circ} \mathrm{C}, 35 \% \mathrm{RH}\right)$ a $2 \log _{10}$ inactivation was measured (Fig. 2a). A log-log comparison of phage inactivation and moisture content showed that the experiments conducted under sunlight adhered to the correlation developed for experiments conducted in the shade (Fig. 3b). This

made with $1 \mathrm{~L}$ of stored urine and dried in the shade at different temperatures and relative humidity: $35-42 \% \mathrm{RH}$ and $5{ }^{\circ} \mathrm{C}(\square), 20^{\circ} \mathrm{C}(\square)$ and $36^{\circ} \mathrm{C}(\square) ; 77 \% \mathrm{RH}$ and $20^{\circ} \mathrm{C}(\bullet)$; $85 \%-93 \%$ RH and $5{ }^{\circ} \mathrm{C}(\Delta), 20^{\circ} \mathrm{C}(\Delta$ [E.1], $\bullet$ [E.2], $\nabla$ [E.4]; see Table 3 ) and $35^{\circ} \mathrm{C}(\Delta)$. Data correspond to those depicted in Fig. 2. (b) Filter cake dried in the sunlight $(\diamond)$ after $0,1,2$ and $5 \mathrm{~h}$ sunlight exposure; (c) comparison between filter cake dried in the shade at $20{ }^{\circ} \mathrm{C}$ and $77-93 \% \mathrm{RH}$ and made from $3 \mathrm{~L}$ (empty symbols) and $4.5 \mathrm{~L}$ (solid symbols) of stored urine. Data for which $\theta_{g}$ was determined by extrapolation are indicated by (*) (see Section 2.6). The continuous line shown in all graphs represents the robust linear regression curve of the whole dataset " $1 \mathrm{~L} /$ in the shade". The dashed line $(-)$ indicates the detection limit. Error bars depict standard deviation of triplicate enumeration of the same sample. 


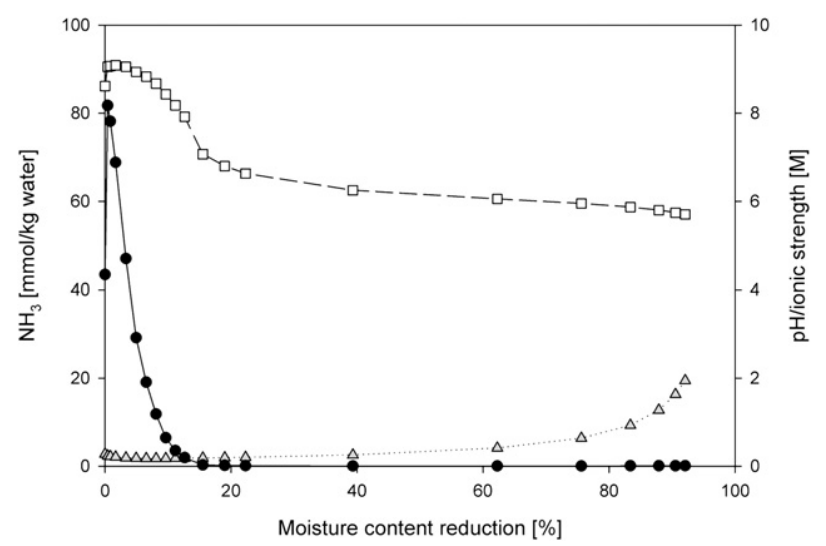

Fig. 4 - Simulation of $\mathrm{NH}_{3}$ concentration (๑), pH ( $\square$ ) and ionic strength $(\Delta)$ as a function of moisture reduction in the cake during drying at $36^{\circ} \mathrm{C} / 36 \% \mathrm{RH}$.

indicates that, despite the thinness of the cake $(1.5 \pm 0.7 \mathrm{~mm})$, the sunlight did not penetrate into the cake to a sufficient extent to significantly contribute to inactivation.

The main contribution of sunlight to the inactivation was an indirect one that resulted from increasing the temperature of the filter cake. Drying the cake in the sunlight can thus enhance inactivation by reducing the moisture of the cake more rapidly, but it must be considered that high temperatures will also cause the release of ammonia from the struvite crystals (Bhuiyan et al., 2008; Frost et al., 2004).

\subsubsection{Effect of filter cake thickness}

To investigate the effect of filter cake's thickness on drying and phage inactivation, cakes made from 3 to $4.5 \mathrm{~L}$ were dried at $20{ }^{\circ} \mathrm{C}$ and $70-90 \% \mathrm{RH}$. Inactivation in these thicker cakes could also be linked to the moisture content with approximately the same correlation as the one obtained for the $1 \mathrm{~L}$ cakes (Fig. 3c). However, a longer drying time was required to reach the same moisture content as the cake made from $1 \mathrm{~L}$ of urine (data not shown). We furthermore caution that the infective virus and moisture content relationship was only tested for urine volumes up to $4.5 \mathrm{~L}$. For the larger volumes commonly used in the field, this relationship remains to be confirmed.

\subsection{Ascaris suum egg inactivation during drying phase}

\subsubsection{Effect of temperature and relative humidity}

Ascaris suum eggs showed no significant inactivation at 5 and $20{ }^{\circ} \mathrm{C}$ after 3 days of drying (0.003-0.01 $\log _{10}$ inactivation) (Fig. 5a). Only the experiments carried out at $35-36^{\circ} \mathrm{C}$ inactivated eggs to a considerable extent: 1.2 to more than $2 \log _{10}$ reduction occurred after 3 days of drying. No significant difference was observed when varying relative humidity at $20{ }^{\circ} \mathrm{C}$, but at $35-36{ }^{\circ} \mathrm{C}$ inactivation was faster at low relative humidity. At $36^{\circ} \mathrm{C}$ and $36 \% \mathrm{RH}$, less than one day was needed to achieve a $2 \log _{10}$ inactivation, while at $35^{\circ} \mathrm{C}$ and $85 \% \mathrm{RH}$, the inactivation was only $1.2 \log _{10}$ after 3 days.

Other researchers have shown that high temperatures are required to inactivate Ascaris suum eggs in buffered ammonia-
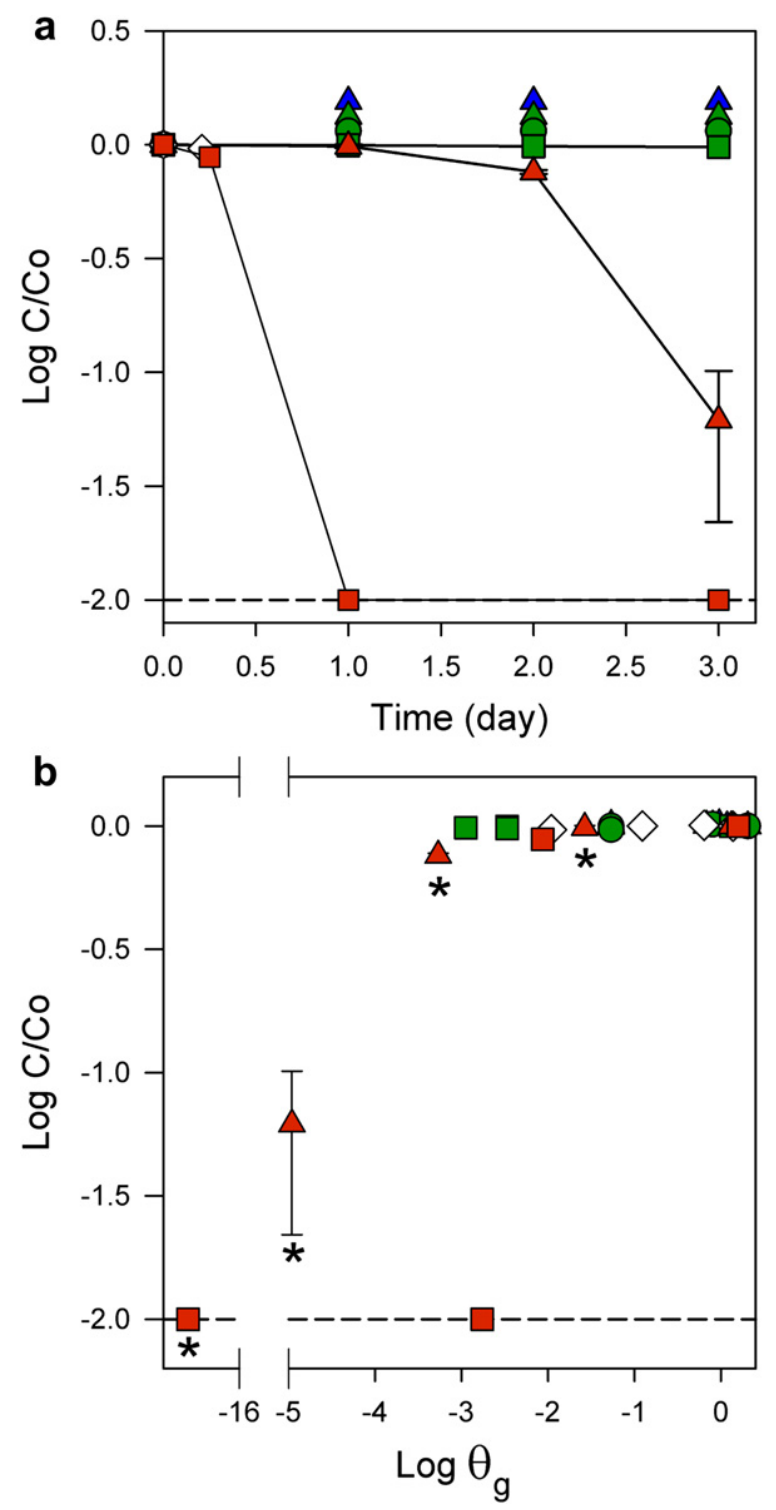

Fig. 5 - Ascaris suum egg inactivation as a function of (a) time and (b) struvite moisture content $\left(\theta_{g}\right)$. Struvite cakes were made from $1 \mathrm{~L}$ of stored urine and dried under different conditions: $5^{\circ} \mathrm{C}$ and $85 \% \mathrm{RH}(\Delta) ; 20{ }^{\circ} \mathrm{C}$ and $90 \% \mathrm{RH}$ $(\Delta), 77 \% \mathrm{RH}(\bullet), 42 \% \mathrm{RH}(\mathrm{B}) ; 35^{\circ} \mathrm{C}$ and $85 \% \mathrm{RH}(\Delta), 36^{\circ} \mathrm{C}$ and $36 \%$ RH ( $\square)$; sunlight $31{ }^{\circ} \mathrm{C},<35 \%$ RH $(\diamond)$. Data for which $\theta_{g}$ was determined by extrapolation are indicated by $(*)$ (see Section 2.6). The dashed line $(-)$ indicates the detection limit. Error bars depict standard deviation of triplicate enumeration of the same sample.

free solutions. Nordin et al. (2009) did not observe any significant inactivation over the course of one month at $24^{\circ} \mathrm{C}$ and $34^{\circ} \mathrm{C}$ in buffered saline solution. Pecson and Nelson (2005) observed a $2 \log _{10}$ inactivation after 3 days at temperatures above $48^{\circ} \mathrm{C}$, but found that inactivation was only minimally influenced by temperatures below $40^{\circ} \mathrm{C}$ over the same time period.

Wharton (1979) demonstrated that the relative humidity has a strong effect on inactivation when Ascaris eggs are exposed to air: at high temperature $\left(30^{\circ} \mathrm{C}\right)$, eggs were inactivated within 3 
days at $0-34 \%$ relative humidity, and within 7 days at $75.5 \%$ relative humidity. At low temperature $\left(16^{\circ} \mathrm{C}\right)$, the time required for inactivation was five to ten times slower. Yet, in more than 95\% relative humidity, all eggs survived for more than 51 days regardless of temperature (Wharton, 1979).

In the struvite cake, Ascaris eggs faced both wet and dry conditions. Immediately after filtration, all eggs were surrounded by urine. As the moisture front within the pores retreated, the eggs became increasingly exposed to air. This is in contrast to the conditions encountered by the phages, whose very small size may allow them to retreat with the moisture front and hence remain immersed in liquid for greater periods of time.

Ascaris inactivation did not exhibit a linear correlation with the moisture content of the cake (Fig. 5b), but our observations suggest that inactivation started when the moisture content was reduced to a sufficient extent such that most eggs were exposed to air. In the case of a filter cake made from $1 \mathrm{~L}$ urine, this moisture content threshold was between 0.001 and $0.01 \mathrm{~g} /$ $\mathrm{g}$ if normalized to $m_{\mathrm{ref}}$, (recall that $m_{\text {ref }}$ additionally has a remaining moisture content of $0.11-0.18 \mathrm{~g}$ moisture/g dry mass). Additional experiments are needed to determine the inactivation threshold more accurately. It is probable that eggs follow the inactivation kinetics observed for desiccation (Wharton, 1979) once the moisture threshold is reached. In this case, inactivation will also take place at temperatures below $36{ }^{\circ} \mathrm{C}$, if struvite drying is sufficiently long to reach a moisture content below the critical threshold.

As for phages, it has been shown that exposure to $\mathrm{NH}_{3}$ causes Ascaris suum egg inactivation (Pecson and Nelson, 2005). At $36{ }^{\circ} \mathrm{C}$ and $\mathrm{pH} 9.0$, in a buffered solution containing approximately $570 \mathrm{mM}$ total ammonia (248 $\mathrm{mM} \mathrm{NH}_{3}$ ), Pecson and Nelson (2005) observed a $2 \log _{10}$ inactivation after 3 days. A similar inactivation was confirmed by Nordin et al. (2009) who did experiments with urine at $34{ }^{\circ} \mathrm{C}, \mathrm{pH}$ 8.8-9.0 and a total ammonia concentration of $439 \mathrm{mM}\left(169 \mathrm{mM} \mathrm{NH}_{3}\right)$. Under the same $\mathrm{pH}$ and temperature conditions, but in diluted urine with 203 and $131 \mathrm{mM}$ total ammonia (59 and $33 \mathrm{mM} \mathrm{NH}_{3}$, respectively), they observed $2 \log _{10}$ inactivation after 6.3 and 8.5 days, respectively.

As discussed above, the $\mathrm{NH}_{3}$ concentration in the cake moisture during drying at $36^{\circ} \mathrm{C} / 36 \% \mathrm{RH}$ evened out below 1 $\mathrm{mmol} / \mathrm{kg}_{\text {water }}$ and the $\mathrm{pH}$ stabilized around neutral within $20 \%$ moisture content reduction (Fig. 4). Despite the neutral pH and low $\mathrm{NH}_{3}$ concentration, we measured a higher inactivation rate than Pecson and Nelson (2005) and Nordin et al. (2009). Thus, $\mathrm{pH}$ and $\mathrm{NH}_{3}$ concentration could not explain the observed inactivation.

Osmotic stress was shown to have no effect on Ascaris eggs during embryonation (Matthews, 1985). Thus, inactivation in our experiment could not be attributed to the increase of ionic strength during struvite drying.

In summary, Ascaris egg inactivation was affected only by desiccation resulting from the loss of moisture in the struvite cake at higher temperatures.

\subsubsection{Effect of the sunlight}

Spindler (1940) showed that Ascaris eggs in shallow water and on a dry surface were completely inactivated by sunlight within a maximum of $9 \mathrm{~h}$ at $30-35^{\circ} \mathrm{C}$. However, after $5 \mathrm{~h}$ of exposure of a struvite cake to sunlight, no significant inactivation was observed ( $<0.02 \log _{10}$ inactivation; data not shown). As for the phage experiments, we assume that most of the Ascaris eggs were well shielded within the struvite cake. In our experiments, the indirect effect of temperature increase and higher evaporation in the sunlight was more important for struvite cakes than the inactivation by solar radiation.

\section{Conclusions}

In this study we investigated the fate of pathogens during two key steps of struvite recovery from urine: 1) struvite precipitation and filtration and 2) struvite drying. Phage \$X174 and Ascaris suum eggs were used as surrogates for human viruses and helminths. Both microorganisms were retained in struvite, although only the large Ascaris suum eggs accumulated (100-fold more concentrated in struvite than in urine on a per mass basis), probably as a result of straining. The concentration of the smaller phage $\Phi \times 174$ could be explained by the amount of phage-containing urine remaining in the struvite cake after filtration. The effluent produced as a result of struvite production contained high amounts of both microorganisms. If the effluent should be used as fertilizer, additional treatment is advisable to reduce the pathogen content.

For filter cakes made from $1 \mathrm{~L}$ urine, the moisture content was shown to be the predominant parameter affecting microorganism inactivation. For phages, we found a linear relationship between the logarithms of microorganism inactivation and the moisture content, even for thicker cakes made from 3 to $4.5 \mathrm{~L}$ of urine. For Ascaris eggs, inactivation occurred only below a certain moisture content threshold (in our experimental conditions $0.001-0.01 \mathrm{~g} / \mathrm{g}$ referring to $m_{\text {ref }}$ ) due to desiccation. Osmotic pressure, as well as biocidal effects of $\mathrm{pH}$ or $\mathrm{NH}_{3}$ in the cake moisture could be excluded as factors causing inactivation. Exposure of the struvite cakes to sunlight had no substantial direct effect on phage $\Phi$ X174 or Ascaris suum eggs. However, heating the struvite cakes in the sun accelerated moisture loss and thereby, inactivation.

Tough our findings remains to be confirmed in the field and for larger scale struvite production, we recommend the following measures for struvite treatment to minimize pathogen concentrations, based on our conclusion that low moisture content is the main factor governing pathogen inactivation:

- Dry filter cakes at elevated temperatures (e.g., in the sun) and/or low relative humidities; ensure, however, that temperatures in the cake do not exceed $40-55^{\circ} \mathrm{C}$ to prevent substantial ammonia loss.

- Create thin struvite filter cakes to minimize the drying phase.

Based on our observations for indicator organisms for human viruses and helminths, we propose that the following should be taken into account during struvite production:

- For viruses: high temperatures or low relative humidity during a short drying phase are more advisable than drying the struvite for a long time. Extending the drying phase 
beyond the time when a steady-state moisture content has been reached will not increase the inactivation significantly; - For Ascaris eggs: only high temperatures, preferably combined with low relative humidity, cause inactivation in the short term. For temperatures below $35^{\circ} \mathrm{C}$, inactivation may occur if the cake is stored for several weeks. However, this assumption remains to be tested.

Inactivation may also occur during urine storage, struvite storage and after applying the struvite to the soil. In order to have a complete evaluation of human health risk of struvite fertilizer produced from urine, further studies on inactivation during production and application of struvite are needed and should be linked in a quantitative microbial risk assessment. Nevertheless, with our study we could demonstrate that given the appropriate temperature and relative humidity conditions - complete drying of struvite in ambient air, coupled with an appropriate urine storage time, would represent an efficient barrier for pathogens.

\section{Acknowledgements}

This work was supported by Angel Fund of the Gemeinnützige Stiftung SYMPHASIS, Zürich. The authors thank Thomas Egli, Thomas Fleischmann, Frederik Hammes, Stefan Koetzsch, Rudolf Schneebeli and Hans-Ulrich Weilenmann for providing the laboratory facilities and for valuable advice; Bastian Etter for the introduction to the struvite production process developed in Nepal; Michael Wächter for the urine composition measurements and the modification of the EQ3/6 database; Brian Sinnet for the filter analysis; Claudia Baenninger, Karin Rottermann and Jean-David Teuscher for chemical analyses; Pietro Lura and Walter Trindler for access to the temperature and relative humidity regulated storage rooms, Pooja Manandar for testing the laboratory methodologies and Stefan Diener for the worm egg counting slides. We furthermore thank three anonymous reviewers for their helpful insights and comments.

\section{Appendix. Supplementary material}

Supplementary data associated with this article can be found, in the online version, at doi:10.1016/j.watres.2011.06.042.

\section{R E F E R E N C E S}

Abegglen, C.K., 2008. Membrane bioreactor technology for decentralized wastewater treatment and reuse. PhD thesis, Nr. 17998, Swiss Federal Institute of Technology Zurich, Switzerland, doi: 10.3929/ethz-a-005745648.

Bhuiyan, M.I.H., Mavinic, D.S., Koch, F.A., 2008. Thermal decomposition of struvite and its phase transition. Chemosphere 70, 1347-1356.

Bouropoulos, N.C., Koutsoukos, P.G., 2000. Spontaneous precipitation of struvite from aqueous solutions. Journal of Crystal Growth 213, 381-388.
Brashear, D.A., Ward, R.L., 1983. Inactivation of indigenous viruses in raw sludge by air drying. Applied and Environmental Microbiology 45, 1943-1945.

Cramer, W.N., Burge, W.D., Kawata, K., 1983. Kinetics of virus inactivation by ammonia. Applied and Environmental Microbiology 45, 760-765.

Davies-Colley, R.J., Donnison, A.M., Speed, D.J., 2000. Towards a mechanistic understanding of pond disinfection. Water Science and Technology 42, 149-158.

Dowd, S.E., Pillai, S.D., Wang, S.Y., Corapcioglu, M.Y., 1998. Delineating the specific influence of virus isoelectric point and size on virus adsorption and transport through sandy soils. Applied and Environmental Microbiology 64, 405-410.

Etter, B., Tilley, E., Khadka, R., Udert, K.M., 2011. Low-cost struvite production using source-separated urine in Nepal. Water Research 45, 852-862.

Feachem, R.G., Bradley, D.J., Garelick, H., Mara, D.D., 1983. Sanitation and Disease: Health Aspects of Excreta and Wastewater Management. Wiley, New York.

Feng, Y.Y., Ong, S.L., Hu, J.Y., Tan, X.L., Ng, W.J., 2003. Effects of $\mathrm{pH}$ and temperature on the survival of coliphages MS2 and Q beta. Journal of Industrial Microbiology \& Biotechnology 30, 549-552.

Frost, R.L., Weier, M.L., Erickson, K.L., 2004. Thermal decomposition of struvite - implications for the decomposition of kidney stones. Journal of Thermal Analysis and Calorimetry 76, 1025-1033.

Goosse, P., Steiner, M., Neuenschwander, W., Udert, K.M., 2009. NoMix-Toilettensystem. Erste Monitoringergebnisse im Forum Chriesbach. Gas Wasser Abwasser 7, 567-574 (NoMix Toilet System, First Monitoring Results in Forum Chriesbach, in German).

Hijnen, W.A.M., Beerendonk, E.F., Medema, G.J., 2006. Inactivation credit of UV radiation for viruses, bacteria and protozoan (oo) cysts in water: a review. Water Research 40, 3-22.

Hoglund, C., Ashbolt, N., Stenstrom, T.A., Svensson, L., 2002. Viral persistence in source-separated human urine. Advances in Environmental Research 6, 265-275.

Hoglund, C.E., Stenstrom, T.A.B., 1999. Survival of Cryptosporidium parvum oocysts in source separated human urine. Canadian Journal of Microbiology 45, 740-746.

Jenkins, M.B., Bowman, D.D., Ghiorse, W.C., 1998. Inactivation of Cryptosporidium parvum oocysts by ammonia. Applied and Environmental Microbiology 64, 784-788.

Jensen, P.K.M., Phuc, P.D., Konradsen, F., Klank, L.T., Dalsgaard, A., 2009. Survival of Ascaris eggs and hygienic quality of human excreta in Vietnamese composting latrines. Environmental Health 8, 57.

Kone, D., 2010. Making urban excreta and wastewater management contribute to cities' economic development: a paradigm shift. Water Policy 12, 602-610.

Kraft, 2010. Final Sampling Report for Products from DoubleChamber UDDTs. EU-SIDA GTZ EcoSan Promotion Project. http:// www2.gtz.de/Dokumente/oe44/ecosan/en-eu-sida-gtz-ecosanpromotion-project-final-report-2010.pdf accessed June 2010

Langergraber, G., Muellegger, E., 2005. Ecological sanitation a way to solve global sanitation problems. Environment International 31, 433-444.

Larsen, T.A., Gujer, W., 1996. Separate management of anthropogenic nutrient solutions (human urine). Water Science and Technology 34, 87-94.

Larsen, T.A., Maurer, M., Udert, K.M., Lienert, J., 2007. Nutrient cycles and resource management: implications for the choice of wastewater treatment technology. Water Science and Technology 56, 229-237.

Lewis, W.K., 1921. The rate of drying of solid materials. Journal of Industrial and Engineering Chemistry 13, 427-432.

Lienert, J., Burki, T., Escher, B.I., 2007. Reducing micropollutants with source control: substance flow analysis of 212 
pharmaceuticals in faeces and urine. Water Science and Technology 56, 87-96.

Love, D.C., Silverman, A., Nelson, K.L., 2010. Human virus and bacteriophage inactivation in clear water by simulated sunlight compared to bacteriophage inactivation at a Southern California Beach. Environmental Science \& Technology 44, 6965-6970.

Matthews, B.E., 1985. The influence of temperature and osmotic stress on the development and eclosion of hookworm eggs. Journal of Helminthology 59, 217-224.

Maurer, M., Pronk, W., Larsen, T.A., 2006. Treatment processes for source-separated urine. Water Research 40, 3151-3166.

Michen, B., Graule, T., 2010. Isoelectric points of viruses. Journal of Applied Microbiology 109, 388-397.

Nordin, A., Nyberg, K., Vinneras, B., 2009. Inactivation of ascaris eggs in source-separated urine and Feces by ammonia at ambient temperatures. Applied and Environmental Microbiology 75, 662-667.

Panchariya, P.C., Popovic, D., Sharma, A.L., 2002. Thin-layer modelling of black tea drying process. Journal of Food Engineering 52, 349-357.

Pecson, B.M., Nelson, K.L., 2005. Inactivation of Ascaris suum eggs by ammonia. Environmental Science \& Technology 39, 7909-7914.

Price, J.W., Miller, M., Hayman, J.M., 1940. The relation of specific gravity to composition and total solids in normal human urine. Journal of Clinical Investigation 19, 537-554.

Pronk, W., Kone, D., 2009. Options for urine treatment in developing countries. Desalination 248, 360-368.

Romer, W., 2006. Plant availability of P from recycling products and phosphate fertilizers in a growth-chamber trial with rye seedlings. Journal of Plant Nutrition and Soil Science. (Zeitschrift Für Pflanzenernährung Und Bodenkunde) 169, 826-832.

Ronteltap, M., Maurer, M., Gujer, W., 2007. The behaviour of pharmaceuticals and heavy metals during struvite precipitation in urine. Water Research 41, 1859-1868.

Sanchez, P.A., 2002. Ecology - soil fertility and hunger in Africa. Science 295, 2019-2020.

Schonning, C., Leeming, R., Stenstrom, T.A., 2002. Faecal contamination of source-separated human urine based on the content of faecal sterols. Water Research 36, 1965-1972.

Schwarzenbach, R.P., Gschwend, P.M., Imboden, D.M., 2003. Environmental Organic Chemistry, second ed. Wiley, Hoboken, N.J.
Shields, P.A., Farrah, S.R., 2002. Characterization of virus adsorption by using DEAE-sepharose and octyl-sepharose. Applied and Environmental Microbiology 68, 3965-3968.

Spindler, L.A., 1940. Effect of tropical sunlight on eggs of ascaris suis (Nematoda), the large intestinal Roundworm of Swine. The Journal of Parasitology 26, 323-331.

Straub, T.M., Pepper, I.L., Gerba, C.P., 1992. Persistence of viruses in desert soils amended with anaerobically digested sewagesludge. Applied and Environmental Microbiology 58, 636-641.

Thompson, S.S., Yates, M.V., 1999. Bacteriophage inactivation at the air-water-solid interface in dynamic batch systems. Applied and Environmental Microbiology 65, 1186-1190.

Udert, K.M., Larsen, T.A., Biebow, M., Gujer, W., 2003. Urea hydrolysis and precipitation dynamics in a urine-collecting system. Water Research 37, 2571-2582.

Udert, K.M., Larsen, T.A., Gujer, W., 2006. Fate of major compounds in source-separated urine. Water Science and Technology 54, 413-420.

Vinneras, B., Nordin, A., Niwagaba, C., Nyberg, K., 2008. Inactivation of bacteria and viruses in human urine depending on temperature and dilution rate. Water Research 42 , 4067-4074.

Ward, R.L., Ashley, C.S., 1977a. Identification of virucidal agent in wastewater-sludge. Applied and Environmental Microbiology 33, 860-864.

Ward, R.L., Ashley, C.S., 1977b. Inactivation of enteric viruses in wastewater-sludge through dewatering by evaporation. Applied and Environmental Microbiology 34, 564-570.

Wharton, D.A., 1979. Ascaris-Sp - water-Loss during desiccation of embryonating eggs. Experimental Parasitology 48, 398-406.

WHO, 2006. Guidelines for the Safe Use of Wastewater, Excreta and Greywater - v. 4. Excreta and Greywater Use in Agriculture. World Health Organization, Geneva, ISBN 9241546867.

Winker, M., Vinneras, B., Muskolus, A., Arnold, U., Clemens, J., 2009. Fertiliser products from new sanitation systems: their potential values and risks. Bioresource Technology 100, 4090-4096.

Winston, P.W., Bates, D.H., 1960. Saturated solutions for the control of humidity in biological-research. Ecology 41, 232-237.

Wolery, T.W., Jarek, R.L., 2003. Software User's Manual EQ3/6 (version 8.0). Sandia National Laboratories, Albuquerque, New Mexico.

Yeager, J.G., Obrien, R.T., 1979. Enterovirus inactivation in soil. Applied and Environmental Microbiology 38, 694-701. 